\title{
ULTRASONOGRAPHIC THYROID FINDINGS
}

\author{
VINICYUS HAMILTON RODRIGUES BARROS, ARIELA MULLER VIEIRA PARENTE
}

\begin{abstract}
INTRODUCTION: Thyroid nodules are by far the most common disorder of the endocrine system. Epidemiological studies have indicated that approximately $5 \%$ of women and $1 \%$ of men residing in areas with sufficient iodine have palpable thyroid nodules.

OBJECTIVE: to evaluate the prevalence of thyroid nodules analyzed by ultrasound.

METHODS: This is a cross-sectional study carried out using thyroid ultrasounds performed from August to December 2019 at an SMS / GO unit. RESULTS: 182 thyroid tests, 162 tests performed on women and 20 on men were analyzed. In the male age group, there is a tendency for normal examinations in the age group from under 30 to 50. In the range of 51 to 60 nodules, two (50\%) and normal (50\%) were found. From 61 to the largest, there is a tendency to nodules. In the age group of women under 30 years old, the prevalence is of normal exams, in the range of 31 to 40 years old, non-nodular changes, of over 51 the nodules smaller than $1 \mathrm{~cm}$. For larger nodules, the range with the highest incidence is 61 to 70 years. Of the 162 women examined, the average age was 50 years old (10 to 95). Of these patients, 30 (18\%) had normal thyroid and 6 (4\%) underwent thyroidectomy. Some type of alteration had been found in 126 patients and the nodular alterations totaled 73 , being 58 (36\%) smaller than $1 \mathrm{~cm}$ and 15 (9\%) larger than $1 \mathrm{~cm}$. In 20 male patients, the mean age was 56 years (25 to 79). Of these nine (45\%) were within normal limits. Some type of change in 11 (55\%) patients and non-nodular changes totaled 6 (30\%) and nodular changes in six, with four (20\%) smaller than $1 \mathrm{~cm}$ and two (10\%) larger than $1 \mathrm{~cm}$.

CONCLUSION: The prevalence of thyroid nodules analyzed by ultrasonography in this population was 48\%. Female patients have a greater tendency to develop nodules, mainly in the 61 to 70 years age group. It is also noticed that there is a relationship between increasing age and thyroid disorders.
\end{abstract}

KEYWORDS: THYROID, DIAGNOSIS, ULTRASOUND.

\section{INTRODUCTION}

Thyroid nodules are by far the most common disorder of the endocrine system. Epidemiological studies have indicated that approximately 5\% of women and 1\% of men living in areas with sufficient iodine have palpable thyroid nodules. However, at age 60, it is estimated that around $50 \%$ of the general population has at least one thyroid nodule ${ }^{1}$.

Most thyroid nodules have benign features; therefore, ultrasound is an integral part of tracking ${ }^{2}$.

Thyroid nodules and thyroid abnormalities are common findings in the general population. Ultrasonography is the most important imaging tool for diagnosing thyroid disease. In most cases, a correct diagnosis can now be made only on ultrasound, together with clinical findings and baseline thyroid hormone parameters ${ }^{3}$.

Ultrasonography allows real-time identification of structures up to $2 \mathrm{~mm}$ in diameter, allowing the visualization of very small tumors of the thyroid and parathyroid glands. In the case of the thyroid, certain internal sonographic features of a nodule are clinically useful because they can correlate highly, but not perfectly, with histology, thus improving a management decision. These methods also allow estimates of global and regional blood flow to the thyroid ${ }^{4}$.

Although many studies have analyzed the association be- tween the characteristics of ultrasound imaging of nodules and the risk of thyroid cancer, most studies have limited their analysis to patients undergoing biopsy, but the adoption of uniform standards for the interpretation of thyroid ultrasound would be a first step to standardize the diagnosis, thus avoiding unnecessary treatments and tests ${ }^{5}$.

Ultrasound classification serves to select nodules with a higher risk of malignancy for fine needle aspiration puncture. Nodules with benign sonographic characteristics have a positive correlation with cytology and pathological examination, therefore, they can be observed clinically ${ }^{6}$.

The present study aims to assess the prevalence of thyroid alterations analyzed by ultrasonography.

\section{METHODS}

This is a cross-sectional study carried out from exams from August to December 2019.

All patients were included and separated into groups, female and male, stratified by age who underwent ultrasound examination in a unit of the municipal health department of Goiânia. All examinations were performed using a $7.5 \mathrm{MHz}$ transducer, with the patient in the supine position and neck extended.

For ultrasonography, the classification proposed by Furla-
1. Unidade da Secretaria Municipal de Saúde de Goiânia
MAILING ADDRESS

VINICYUS HAMILTON RODRIGUES BARROS

R. 1124, 319-381 - St. Marista,

Goiânia - GO, 74175-080 
netto et al. ${ }^{7}$ was used. (1) normal; (2) non-nodular changes; (3) nodules smaller than $1 \mathrm{~cm}$; (4) nodules of $1 \mathrm{~cm}$ or more and (5) patients that underwent thyroidectomy.

This research project was based on Resolution NO. $466 / 2012$, thus ensuring the rights of those involved, approved by the Ethics Committee appointed by Plataforma Brasil.

\section{RESULTS}

182 thyroid exams were analyzed, 162 exams were performed in women and 20 in men.

\begin{tabular}{lll}
\hline Aspect of USG & Absolute frequency & Relative frequency \\
\hline Normal & 30 & $18 \%$ \\
Non-nodular alterations & 53 & $33 \%$ \\
Nodules $<1 \mathrm{~cm}$ & 58 & $36 \%$ \\
Nodules $>=1 \mathrm{~cm}$ & 15 & $9 \%$ \\
Thyroidectomy & 6 & $4 \%$ \\
TOTAL & 162 & $100 \%$ \\
\hline
\end{tabular}

Tabela 1 - Distribuição das Características ultrassonografias das tireoides de mulheres atendidas na SMS/GO, Goiânia, 2019.

\begin{tabular}{lll}
\hline Aspect of USG & Absolute frequency & Relative frequency \\
\hline Normal & 9 & $45 \%$ \\
Non-nodular alterations & 5 & $25 \%$ \\
Nodules $<1 \mathrm{~cm}$ & 4 & $20 \%$ \\
Nodules $>-1 \mathrm{~cm}$ & 2 & $10 \%$ \\
Thyroidectomy & - & - \\
TOTAL & 20 & 100
\end{tabular}

Tabela 2 - Distribuição das Características ultrassonografias das tireoides de homens atendidos na SMS/GO, Goiânia, 2019.

\begin{tabular}{lllllll}
\hline Aspect of USG & $<30$ & $\mathbf{3 1}$ to 40 & $\mathbf{4 1}$ to 50 & $\mathbf{5 1}$ to 60 & $\mathbf{6 1}$ to 70 & $\mathbf{7 1 >}$ \\
\hline Normal & $11(5)$ & $2(9)$ & $5(17)$ & $8(17)$ & $3(10)$ & $1(8)$ \\
Non-nodular alterations & $3(15)$ & $11(50)$ & $14(46)$ & $14(31)$ & $6(19)$ & $5(38)$ \\
Nodules $<1 \mathrm{~cm}$ & $6(35)$ & $8(36)$ & $8(27)$ & $19(41)$ & $12(39)$ & $5(38)$ \\
Nodules $>=1 \mathrm{~cm}$ & - & 0 & $2(7)$ & $3(7)$ & $9(29)$ & $1(8)$ \\
Thyroidectomy & - & $1(5)$ & $1(3)$ & $2(4)$ & $1(3)$ & $1(8)$
\end{tabular}

Tabela 3 - Distribuição das Características ultrassonografias das tireoides em relação a faixa etária de mulheres atendidas na SMS/GO, Goiânia, 2019.

\begin{tabular}{lllllll}
\hline Aspect of USG & $<\mathbf{3 0}$ & $\mathbf{3 1}$ to $\mathbf{4 0}$ & $\mathbf{4 1}$ to 50 & $\mathbf{5 1}$ to 60 & $\mathbf{6 1}$ to $\mathbf{7 0}$ & $\mathbf{7 1}>$ \\
\hline Normal & $1(50)$ & $1(100)$ & $2(50)$ & $2(50)$ & $1(20)$ & $2(50)$ \\
Non-nodular alterations & $1(50)$ & - & $2(50)$ & - & $1(20)$ & $1(25)$ \\
Nodules $<1 \mathrm{~cm}$ & - & - & - & $1(25)$ & $2(40)$ & $1(25)$ \\
Nodules $>=1 \mathrm{~cm}$ & - & - & - & $1(25)$ & $1(20)$ & - \\
Thyroidectomy & - & - & - & - & - & - \\
\hline
\end{tabular}

Tabela 4 - Distribuição das Características ultrassonografias das tireoides em relação a faixa etária de homens atendidas na SMS/GO, Goiânia, 2019.

\section{DISCUSSION}

The ultrasound (US) is the main imaging modality for detecting, characterizing and monitoring thyroid nodules, in addition to evaluating the neck after thyroidectomy. A comprehensive examination of the thyroid US requires assessment of the size and morphological features of the thyroid gland; documentation of any nodules, including size, shape, echogenicity, and presence of suspicious features; evaluation of lymphadenopathy in stations I-VI; and providing recommendations for fine-needle aspiration biopsy (FNAB) ${ }^{8}$.

The thyroid ultrasound is an excellent method for detecting nodules, with a sensitivity of approximately $95 \%$, superior to other more sophisticated methods, such as computed tomography (CT) and nuclear magnetic resonance (NMR) ${ }^{9}$.

In the age group of men, there is a tendency for normal exams in the age group under 30 to 50 years of age. In the range of 51 to 60 , nodules were found in two (50\%) and two were normal $(50 \%)$. From 61 to older, there is a tendency to nodules.

In the age group of women younger than 30 years of age, the prevalence is normal exams, in the range from 31 to 40 years of age, non-nodular alterations, with nodules smaller than $1 \mathrm{~cm}$ over 51 years old. For larger nodules, the range with the highest incidence is between 61 and 70 years of age.

According to the Brazilian Society of Endocrinology and Metabology, about $4-7 \%$ of women and $1 \%$ of men have palpable thyroid nodules, with nodules larger than $1 \mathrm{~cm}$, corroborating our findings. Kimura et al. $^{10}$ ultrasound studies show that this prevalence is even higher, ranging from 19\% to $67 \%$, with a higher incidence in women and elderly people. This is extremely important since the management of thyroid nodules is based on the fact that, although the vast majority represent benign lesions, it is necessary to exclude thyroid cancer, which occurs in $5 \%$ to $10 \%$ of cases. Rio et al.11 reveal that there is a higher risk of malignancy in men, with hypoechogenic nodules, with microcalcifications and inversely related to age, and that the TSH level is not an independent predictor of malignancy.

Of the 162 women examined, the mean age was 50 years (10 to 95$)$. Of these patients, $30(18 \%)$ had normal thyroid and six (4\%) underwent thyroidectomy. Some type 
of alteration was found in 126 patients and nodular alterations totaled 73, $58(36 \%)$ smaller than $1 \mathrm{~cm}$ and $15(9 \%)$ larger than $1 \mathrm{~cm}$.

In 20 male patients the mean age was 56 years $(25$ to 79). Of these, nine (45\%) were within the normal range. Some type of alteration was found in ${ }^{11}(55 \%)$ patients and non-nodular changes totaled six $(30 \%)$ and nodular changes four (20\%) smaller than $1 \mathrm{~cm}$ and two $(10 \%)$ larger than $1 \mathrm{~cm}$.

Cavallo et al, when evaluating 1003 nodules from 659 patients, found that $26 \%$ were malignant. Nodules $<2 \mathrm{~cm}$ had the highest malignancy rate $(30 \%)$. The risk was similar ( $\pm 20 \%$ ) for nodules $\geq 2 \mathrm{~cm}$. Decreasing rates of malignancy were observed with increasing size $(57 \%$ for nodules $<1 \mathrm{~cm}$ to $20 \%$ for nodules $>6 \mathrm{~cm}$ ). In slices with ultrasound size of $2-5 \mathrm{~cm}$, smaller nodules had higher rates of malignancy than larger nodules, so the size of thyroid nodules is inversely related to the risk of malignancy, as larger nodules have lower rates of malignancy ${ }^{2}$. Therefore, follow-up should be done in patients with smaller nodules. In 992 patients, followed up for five years, they observed that $15.4 \%$ of the nodules had grown (increase of two diameters $\geq 20 \%$ ); $18.5 \%$ decreased in size; and only $0.3 \%(5)$ of the nodules were malignant. This indicates that the treatment of asymptomatic patients is unnecessary ${ }^{3}$ thus revealing the importance of clinical monitoring of these patients. Nodules larger than $1 \mathrm{~cm}$ should always be evaluated and nodules smaller than $1 \mathrm{~cm}$ should be evaluated if they present ultrasound characteristics suggestive of malignancy?

It is also perceived that there is a relationship between increasing age and thyroid alterations, therefore, thyroid ultrasonography requires experience and understanding of thyroid anatomy and pathology. It cannot be ideally performed by a technician who simply takes pictures and then sends the photographs off for later interpretation. The thyroid ultrasonographer must master thyroid palpation, anatomy and pathophysiology and must have special training in ultrasound procedures, meticulous attention to detail and adequate time to perform a complete examination ${ }^{4}$.

Rahal Junior et al. ${ }^{12}$ recommends to the ultrasonographer that the TI-RADS classification be performed to avoid unnecessary fine needle aspiration puncture and to help in decisions about when it should be done. This classification is known to improve communication and reduce confusion between physicians and patients.

\section{CONCLUSION}

The prevalence of thyroid abnormalities analyzed by ultrasound in this population was $48 \%$.

Female patients have a greater tendency to develop nodules, especially in the 61 to 70 year age group.

It is also perceived that there is a relationship between increasing age and thyroid alterations.

\section{REFERENCES}

1. Paschou, S. A; Vryonidou, A; Goulis, D. G. Thyroid nodules: guide to assessment, treatment and follow-up. Maturitas, 2017;1 (96):1-9.
2. Cavallo A, Johnson DN, White MG, Siddiqui S, Antic T, Mathew M, Grogan RH, Angelos P, Kaplan EL, Cipriani NA. thyroid nodule size at ultrasound as a predictor of malignancy and final pathologic size. Thyroid., 2017;27(5):641-650.

3. Dietrich CF, Müller T, Bojunga J, Dong Y, Mauri G, Radzina M, Dighe M, Cui XW, Grünwald F, Schuler A, Ignee A, Korkusuz H. Statement and recommendations on interventional ultrasound as a thyroid diagnostic and treatment procedure. Ultrasound Med Biol., 2018;44(1):14-36.

4. Blum M. Technical aspects of thyroid ultrasound. Disponível: https:// www.uptodate.com/contents/technical-aspects-of-thyroid-ultrasound. Acesso em 12.02.2020.

5. Smith-Bindman R. Risk of thyroid cancer based on thyroid ultrasound imaging characteristics results of a population-based study. JAMA Internal Medicine. 2013;173(19).

6. Tomimori EK. Avaliação ultrassonográfica dos nódulos tireóideos: comparação com exame citológico e histopatológico. Arq Bras Endocrinol Metab 2004;48(1):105-113.

7. Furlanetto TW, Peccin S, Schneider MAO, Zimmer AS, Reis PS, Genro SK, Ferreira EV, Bittelbrum F, Müller AS, Silva RW, Siqueira IR, Silveira MF. Prevalência de nódulos de tireoide detectados por ecografia em mulheres após os 40 anos. Rev. Assoc. Med. Bras. 2000;46(4):331-334.

8. Stewart SA, Rajaraman M, Costa AF. Web-based tool for standardized reporting of thyroid ultrasound studies. American Journal of Roentgenology., 2018;1:39-42.

9. Maia AL, Ward LS, Carvalho GA, Graf H, Maciel RMB, Maciel LMZ, Rosário PW, Vaisman M. Nódulos de tireóide e câncer diferenciado de tireóide:consenso brasileiro. Arq Bras Endocrinol Metab, 2007;51(5):867-893.

10. Kimura ET, Tincani AJ, Ward LS, Nogueira CR, Carvalho GA, Maia AL, Tavares MR, Teixeira G, Kulcsar MAV, Biscolla RPM, Cavalcanti CEO, Correa LAC, del Negro A, Friguglieti CUM, Hojaij F, Abrahão M, Andrada NC. Doença Nodular da tireoide: Diagnóstico. Diretrizes Clínicas na Saúde Suplementar da Associação Médica Brasileira e Agência Nacional de Saúde Suplementar. Disponível em: https:// amb.org.br/files/ans/doenca_nodular_da_tireoide-diagnostico.pdf, acessado dia 23 de Agosto 2021.

11. Rio ALS \& Furlanetto RP. Avaliação de fatores clínicos, laboratoriais e ultrassonográficos preditores de malignidade em nódulos tiroidianos. Arquivos Brasileiros de Endocrinologia \& Metabologia 2021;55(1): 29-37.

12. Rahal Junior A, Falsarella PM, Rocha RD, Lima JPBC, Iani MJ, Vieira FAC, Queiroz MRG, Hidal JT, Francisco Neto MJ, Garcia RG, Funari MBG. Correlação entre a classificação Thyroid Imaging Reporting and Data System [TI-RADS] e punção aspirativa por agulha fina: experiência com 1.000 nódulos. Einstein (São Paulo), 2016;14(2): 119-123. 